\section{ROYAL AUSTRALASIAN COLLEGE OF SURGEONS}

OPENING OF THE BUILDING AT MELBOURNE

BY

SIR D'ARCY POWER, K.B.E., F.R.C.S.

The Royal Australasian College of Surgeons has had a local habitation and a name in Collins Street for the last eight years, and Collins Street is the medical centre of Melbourne. Since March 4th, 1935, the College has had a palatial home in Spring Street, near the Parliament House, where the old High School had its quarters. The site was given by the Victorian Government, and a generous donation of $£ 1,000$ from Dr. A. E. Rowden White defrayed a part of the cost of the building.

The opening day was hot and sunny. Doctors in academic dress, and ladies in brilliant colours, waited under the shade of the trees until Sir Holburt Waring, President of the Royal College of Surgeons of England, and Sir Henry Newland of Adelaide, President of the Royal Australasian College of Surgeons, made their appearance. A procession was formed, the two Presidents being preceded by the Mace-bearer, carrying the Great Mace brought by Mr. C. H. Fagge two years ago as a gift from the Council of the Royal College of Surgeons of England. Sir Holburt Waring unlocked the door with a golden key, declared the building open, and read a message from His Majesty the King expressing his sincere good wishes for the welfare and prosperity of the College. The Hall filled quickly, the seats of honour being occupied by Sir Stanley Argyle, Premier of Victoria, Sir Richard Stawell, President-Elect of the British Medical Association, Mr. Leighton Irwin, the architect, Sir Louis Barnett and Sir Carrick Robertson of New Zealand, and the surgical representatives from Great Britain, Scotland, Canada, South Africa, and the United States. The body of the Hall was filled with surgeons, many of whom had travelled hundreds of miles from every point of the vast Gommonwealth. Sir D'Arcy Power read the opening address, which he had entitled "How Surgery came to Australasia," and an hour and a half later the audience was enjoying tea in the houses of their friends.

A very large gathering met in the evening at the Wilson Hall of the Melbourne University, the chair being taken by Sir William Irvine, the Deputy Governor, in the absence on account of illness of the Governor, Lord Huntingfield. Honorary Fellowships of the College were formally conferred by Sir Henry Newland, P.R.A.C.S., upon Sir Holburt J. Waring, Bt., and Sir D'Arcy Power, K.B.E., as representing England; Professor John Fraser and Mr. Henry Wade of Edinburgh ; Professor E. Archibald of Canada ; Professor C. F. M. Saint of South Africa ; Dr. Donald O. Balfour, President of the American College of Surgeons; Dr. Dean Lewis of the Johns Hopkins Hospital, Baltimore, from the United States ; and Professor F. Wood-Jones of Melbourne University. Sir Holburt Waring took the opportunity of presenting Mr. Edgar S. J. King of Melbourne with the Jacksonian Prize, which he had distinguished himself by gaining on two occasions. The meeting concluded with an admirable address, faultlessly delivered by Professor WoodJones, F.R.S., on "The Master Surgeon." The rest of the week was devoted to the reading of papers on subjects connected with surgery.

The staff work of the two large meetings was admirable. The details had been well thought out, and every person knew beforehand where he had to go and what he had to do. It showed that the medical profession in Australia, owing to the size of the continent and the necessity for numerous conferences, have become past-masters in organizing. It augurs well for the success of the British Medical Association Meeting in September.

By good fortune I was able to attend the annual meeting of the Tasmanian Branch at Hobart, under the presidency of Dr. W. L. Crofton, as well as a pleasant gathering in Perth. At both places we sat down to an excellent banquet, and I learnt that " tea and damper" were no longer in favour as the staple diet, at any rate in the cities of the Commonwealth.

Australian hospitality is proverbial, and for us it knew no bounds. Mr. Malcolm Brodie, a leader in the shipping world, and his sister, Miss Brodie, took my granddaughter and myself into their home, although we were total strangers, and in the course of the few days we stayed with them cemented a firm friendship. Invitations to garden parties, lunches, dinners, and to that unique Australian institution " morning tea," were showered upon the fortunate representative surgeons, who survived them all in the best of health.

The vastness of the continent was positively appalling to a week-end visitor like myself. Some 1,500 miles from Perth to Adelaide (and four hundred of that desert), six hundred miles from Adelaide to Melbourne, and yet another six hundred from Melbourne to Sydney. We have no idea of such distances in England, or of the problems which the surgeon has to solve in the course of his practice. We know far too little at present of the grand work carried out by John Flynn. By his energy Bush hospitals have been planted in various parts of the remote Inland. He has also inaugurated an aerial medical service to bring help to homesteads and villages which are sometimes four hundred and five hundred miles from the nearest doctor. The crowning work has been to invent a portable wireless set which can transmit as well as receive messages. The motor power is supplied by a treadle; the transmitting board is like the keyboard of a typewriter, but when the letters are pressed they are transmitted in Morse. An illiterate mother, therefore, who knows little more than her alphabet, can spell out a message which appears at the other end in Morse, and can receive her answer in words.

Each of the towns we visited appeared to us as garden cities. The houses, separated from each other, and each with its well-kept garden, were of the bungalow type. The independence characteristic of the Australians has insured that no two bungalows should be alike in their architecture, and the majority are owned by their occupants. Unfortunately the flat system is coming into vogue, though fortunately even the flats retain the bungalow type.

\section{BRITISH ASSOCIATION OF RADIOLOGISTS}

During the past year a new society, the British Association of Radiologists, has been formed, under the presidency of Dr. James F. Brailsford, for the advancement of medical radiology in all its branches, with particular reference to its clinical, ethical, educational, and economic aspects. One of the principal objects of the association is to hold an annual meeting or congress in June at one of the great centres, metropolitan or provincial, at which members from all over the country may meet and obtain first-hand knowledge of work in other centres.

The first annual meeting will be held at Birmingham in June, 1935, and will extend over two days. The programme will include a reception, presidential address, hospital visits, an exhibition of radiograms of bone and joint conditions, and an annual dinner. The date of the meeting and the details of the programme will be announced shortly.

The association was formed with an initial membership of about one hundred. Membership is limited to registered medical practitioners who have been engaged solely in the practice of radiology, or radiology and therapeutics, for at least five years. Those who have been in practice for a shorter period are eligible as associate members until they qualify as full members.

Election to the association is made at the annual general meeting on the nomination of the council. Candidates who are elected at that meeting are entitled to attend the subsequent functions of the congress. Proposal forms for membership may be obtained from the honorary secretary, Dr. S. Cochrane Shanks, 68, Harley Street, London, W.1. 